\title{
The Gender Perspective Of Psychological Challenges Experienced By Residents In Homes For The Aged In Nigeria
}

\author{
Winifred Uju Osakwe-Ogo \\ Department Of Adult Education, Faculty Of Education. \\ Nnamdi Azikwe University, Awka. Nigeria
}

\begin{abstract}
The purpose of the study was to identify the gender differentials in psychological problems experienced by residents of homes for the aged in Nigeria as well as the strategies for reducing the problems. Two research questions and two hypotheses guided the study. The design was descriptive, involving 235 residents of mission and government-managed homes for the old selected through cluster random sampling. Data were collected through a 108 item research-developed questionnaire organized in four sections. Mean ratings were used in answering the research questions, while t-test statistic was used in testing the hypotheses at 0.05 level of significance. Findings indicated that residents of old people's homes experience a series of psychological challenges such as depression, insomnia, amnesia, emotional problems and fear. While, female residents rated emotional challenges and fears as more contributory to their psychological challenges and male respondents rated self-esteem as significant influencers to psychological challenges. In addition, the residents perceived that policy enforcement, pension policies and medical services as key strategies to reducing psychological challenges and that resident of mission-managed homes rated their experiences of social problems more than the residents in government managed homes. Based on this a number of recommendations were made which include; policy review of existing policies on the care of the aged in the society, pension administration review, more participation by the Nigerian government, re-training and employment of care-givers by non-governmental bodies, missionary and the government, integrating a gender based approach in counseling, ensuring adequate medical facilities are available, fast tracking medical response services to members of this elite group.
\end{abstract}

Keywords: OLD, Home for the Aged, Gender

\section{INTRODUCTION}

It is the dream of every individual that after years of toiling and sacrifices that they would someday be catered for by family which would provide him love, support and attention while watching their grandchildren grow and their savings and family feed and accommodate them (Dada, 2005). They are optimistic that their old age would be characterized by respect, dignity, comfort, and admiration in the bosom of their young ones (Obadina, 2005). Nomaguchi (2012) asserted that, "when we grow old, we expect the final years of our life to be less socially and psychological burdensome."

Ferris (2003) pointed out that there is no specific test for biological age, which is judged on the basis of overall impression and external appearances and because individuals differ greatly in the physical and mental attributes with advancing years, it is extremely difficult to define the term 'Old'. A person's chronological age is closely associated with describing him or her as old, but by no means a perfect index of his physical and mental capacities or his life expectation. Obadina (2005) noted that old people are young people in mature body, most of them wise beyond their years. The issue of stating categorically who is an old person creates a big controversy and misunderstanding even among authorities in developed world. According to Beers and Berkow (2004) many people are vigorous and active at 65 years; others are sick and 
inactive at 40 years. It can thus be deduced that old age is not a matter of years as some individuals remain young in their eighties while others seem old in their sixties. In most official documents and statistics, the elderly are considered to be all those who qualify for the retirement pension. In addition, a significant number of them are bedridden, household or seriously incapacitated, either by general infirmity or by specific disabilities such as blindness, deafness or vertigo; about 5 percent exhibit psychiatric abnormalities, but not all are treated. In Nigeria, 65 years is the retirement age. Consequently, those aged 65 are regarded as old people who may not be able to engage in active services, but might depend on their friend and relations for survival (Obadina, 2004; Tanyi et al, 2018). Pension schemes are put in place for retired peopled aged 65 years and above.

\section{Caring for the Aged in the Society}

In Nigeria there are little or no legislations about the elderly persons (Tanyi et al, 2018). The available ones are not implemented. Pensions are difficult to collect making those that are without relatives to care for them and those in the Old peoples home suffer hardship (Adebowale et al., 2012). The nature and reality of ageing has continued to create concerns and challenges across societies and in developed and developing countries policies and programmes are constantly being formulated to reduce the impact of ageing on the elderly. One of these efforts at providing care for the old is the establishment of institutions for Old otherwise known as "Home for the Aged".

Homes for the aged are institutions established to cater for a lot of people that cut across destitute, retirees and mentally retarded elderly individuals. These Institutions for the old refer to homes or welfare centres where old people are cared (Ncube, 2017). Bamidele (2005) described Homes for the Aged as homes meant specifically for the accommodation and care of the aged. In such homes, institutional care such as feeding, clothing, healthcare and social activities are provided for the old. The goals of such establishment are to alleviate the plight of the old by providing economic, social and psychological support to the residents (Adebowale et., 2012).

For a significant number of aged ones the question of independent living versus some kind of institutional care is a matter of great concern. Dada (2005) highlights that some of the rationales behind why the aged resort to homes for the aged includes:

1. That they do not have any surviving relative

2. They have no residency.

3. They are physically challenged and dependent.

4. They have health challenges

\section{Institutions for the Elderly in Nigeria}

Nationally, there are 13 homes for the aged institutions serving Nigerian's population of about 95 million (Obadina, 2005). A reasonable number of them are owned by Missionaries in Nigeria. Unfortunately, the Nigerian government does not have any befitting well equipped home for the aged in the country. Rather it is the missionaries who invested heavily in the care and providing of facilities for the aged in the country. This situation has left most families more willing to leave their aged parents or relations in these homes. The state of the government owned institutions could best be described as extremely deplorable or even non-existent in some cases. According to Shofoyeke \& Amosun (2014) the government has rather placed more emphasis on policy formulation for the aged instead of implementation of measures even so they are limited. It is critical therefore to highlight that there has no organized study into the state, welfare and care of the aged in the Nigerian society. The National development policy for 
Nigeria so far remains the best guideline from the government for those concerned with the welfare of Nigerian aged citizens.

\section{Challenges associated with caring for the Aged in Elderly-Homes}

Scholars have argued that the idea of homes for the aged is alien to the Nigerian culture and in places where they exist, they hardly satisfy the needs of the elderly residents (Foudau, 2005) and the residents are bound to suffer some psychological problems which are related to deprivations in their emotional and mental needs such as friendship, love, counseling, belongingness, self-esteem and others (Maslow, 1948).

Obadina (2005) stated that the residents are always depressed, alienated from their ancestral homes or community, stigmatized, lonely and develop a culture of dependence. Routine and regulated life, which gives room to boredom and hopelessness characterize the feelings of these residents. Mushtaq, Shoib, Shah \& Mushtaq (2014) reported that among the psychological consequences are feelings of helplessness, depression, alienation and anxiety. The residents do not participate in activities in their ancestral hometowns and villages anymore (Onyeabor, 2004). They become totally cut off from other members of their society. They are alienated and stigmatized and called all sorts of name. Some look on them with scorn and degradation. This situation further depresses the old people and makes their life worthless.

\section{Gender Differentials in the Problems Experienced by the old}

Studies have shown that there are gender differentials against females in the problems of the aged (Ikoh, 2005; Austen, 2016; Kolawole \& Adeigbe. 2016). The family into which a Nigerian woman marries is based on exploitation of her labour because of "duty towards family" (Kolawole \& Adeigbe, 2016). She has not only to play the role of wife and mother and daughter-in-law but also carry the major responsibility of care giving to the old, sick and others. As most women are younger than their husbands and outlive them and as their status is dependent on the husband and in his absence it degrades further. Therefore, most of these women make a heavy emotional investment in their sons who are expected to take care of them when they grow old and frail (Bahr \& Bahr, 2001; Ene-Obong \& Onuoha, 2017). But how fruitful does this investment prove is up for debate. Aged women are particularly at risk in Nigerian society because most of them live in the shadow of the males throughout their lives. In most cases they do not earn money and even when they do, their employment is often guided by family considerations, so most of them take up casual employment or are under employed and they also shoulder family re5ponsibilities (Obadina, 2005). Moreover, as EneObong \& Onuoha, 2017) pointed out, in some cases, their earnings are managed by the male counterpart, so for all practical purposes some of them have no knowledge of how to use them. The labour force participation also tells the same tale of a disadvantaged position with $59 \%$ of men as compared to $18 \%$ women being included in the labour force in the 60+ age group (NPC, 2004). It is easy to defraud such women as their world view, in most cases, is limited to family and kin-group matters. This also applies to ownership of property. Most of the women do not own property and even when they own it they do not manage it (Irvine, 1986). They are completely dependant on the male members of the family for fulfillment of all their basic needs (Hashimoto, 1990). They cannot even go to the local doctor without a male relative accompanying them, even when they are fit to move around (Ferris, 2003) and with age this dependence increases.

\section{THEORETICAL FRAMEWORK}

Old age is a condition necessitated by ageing. Aging has been defined by Leiken \& Lipsky (2002) as the decline overtime, of the body's organ systems. According to them ageing is a 
distinct process, there is consensus that the mechanisms are likely multifunctional, environmentally influenced, and species-peculiar, if not organ and sell-specific, making the paucity of available human data particularly problematic. Based on this, three theories can be linked to this study.

The first theory proposes that as animals typically yield to the demands of nature prior to attaining their maximum life span, ageing could indicate mutations that weaken long-term survival. The second theory known as "pleiotropic antagonism" proposes that ageing could be influenced by the late and deleterious impacts of genes which are preserved due to the advantages they offer to survival before reproduction. The third and final theory relates to biological riches that see extrinsic dangers are comparatively reduced: In these types of environment could select for transformations that impact the process of ageing since it could permit an animal to reproduce and safeguard a greater number of lives. According to the Beers and Berkow, (2004) Ageing in the $21^{\text {st }}$. Century is a story of success, but it is also a story with sub plots of concern and peril".

These theories indicate that the body changes with ageing because changes occur in individual cells and in whole organs. These changes result in changes in function, in appearance and this is the experience ageing. As the individual ages, the cells in the body ages as well and therefore function less well. Cells may die eventually because they are damaged. This might be as a result of harmful substance in the environment, such as radiation, a sunlight and chemotherapy drug. Acids from some products, called free-radicals may also damage cells. Apoptosis i.e programmed death of cell can also be a cause of death of cell. This might occur when new cells replace old cries. This could also be a kind of cell suicide. Cells can so die as a result of limited number of times it can divide (Ferris, 2003). This mechanism is called Telomeres. Telomere is used to move the cells genetic material in preparation for cell division. Every time a cell divides, the telomeres shorten a bit. Eventually becomes so short it cannot divide again. How well organs function depends on how well the cells within them function. "Older cells function less well. In organs like the testes, ovaries liver and kidney decreases markedly as the body ages and are not replaced once they die, unlike the brain, which does not lose large number of cells".

In any case there is no way of predicting how an individual will age, because each person ages at different pace. In addition how well person takes care of the body influences how the person ages. Nonetheless, some changes are almost universal. These include deterioration in sight, hearing, mouth and nose, skin, Bones and joints, muscles and body fat, Brain and nervous system, heart and blood lungs, digestive system, kidney and urinary tract, reproductive organs endocrine systems and the immune system (Obadina, 2005).

\section{Objectives of the study}

- To determine if there is gender differential in the psychological problems experienced by male and female residents of homes for the aged.

- To determine the strategies for reducing psychological challenges experienced by male and female residents of homes for the aged.

\section{Significance of the Study}

- Since a significant number of these homes are run by the missionaries, this research will prove immensely useful to the missionaries in assisting them with caring for the old particularly on the basis of improving their services to be suitable to both male and female residents. 
- Social welfare officers will benefit from the findings of this study because they will see the range of psychological problems that are peculiar to each gender and design strategies to reduce their plight.

- Counselors will also benefit from the findings of this study. A revelation of the psychological problems peculiar to each gender of residents in these homes assist them draft strategies and approaches in providing counseling for male and female residents of urban and rural homes, whether the homes are managed by missions or by state government, when they go on visit or as resource persons to these homes.

- Government will benefit from the findings of this study. They will see the extent the residents in their homes. The strategies for improvement would inspire the commitment to the welfare of the Old and might motivate them to recognize care of the old as a national issue and not just a filial affair. Based on the findings, they will assess the need for regular payment of pensions and providing support for the establishment and management of homes for the aged.

- Findings will also inspire further research into the area gender specific care in the institutionalization of the old.

\section{Research Questions}

The following research question guided the study;

- To what extent do the designated psychological problems (self-esteem, emotional, fear, amnesia and depression) impact the female residents of the old people's homes?

- To what extent do the designated psychological problems (self-esteem, emotional, fear, amnesia and depression) impact the female residents of the old people's homes?

\section{Hypotheses}

Two hypotheses were tested in this study at the .05 level of significance. These are:

Ho1: There is no significant difference between the mean responses of male and female residents on their perception of the designated psychological problems.

Ho2: There is no significant difference between the mean ratings of male and female residents on the extent to which designated strategies should be adopted to reduce the identified psychological problems.

\section{METHODOLOGY}

The study was designed as an opinion survey and sought the opinion of the respondents being studied.

\section{Scope of the Study}

The study which sought the opinions of the male and female respondents residing homes for the aged on the psychological problems experienced by them was geographically limited to homes for the aged in the Southern parts of Nigeria.

\section{Population of the Study}

The population for the study was targeted at the 585 residents spread across the homes for the aged in the area of the study. Three hundred and twenty-five of the residents are females, while two hundred and sixty are males (UNICEF, 2005).

\section{Sample for the Study}

The Sample for the study comprised of 241 residents which was obtained using the cluster random sampling approach. The 13 homes for the aged were grouped according to their management i.e mission and government managed. Then from each of the clusters, three homes were randomly selected. Thus a total of 6 homes representing 46.15 percent of the total 
number of homes were randomly selected for the study. Those selected were the Home for the elderly Calabar, Cross-River State; old peoples home, Warri Delta State, and the little sisters of poor and elderly Enugu, Enugu state for mission-managed homes. Yaba old peoples home, Lagos, Lagos state, old peoples home Kano, Kano state and home for the elderly and mentally retarded, Ekwulumili Anambra state were selected from the government-managed homes.

\section{Instrumentation}

A structured questionnaire was designed and rated on a 5 point scale as the instrument and was grouped into Section A, B, C which addressed personal data, psychological problems and strategies for improvement respectively. The instrument was validated within face and content parameters were employed for collection of information. The data collected from the respondents were analyzed and the internal consistency of the questionnaire determined, using the Cronbach Alpha Coefficient formula.

Formula for Cronbach Alpha method is:

$$
\frac{(\mathrm{n})}{(\mathrm{N}-1)} \frac{\left(\mathrm{S}_{1}=\underline{S}_{1}{ }^{2}\right)}{(5 \mathrm{X})}
$$

where

$\mathrm{n}=$ the number of items in the instrument

$s_{1}=$ the variance of a single item

$s_{\mathrm{x}}=$ the variance of the whole instrument

Reliability co-efficient was calculated for the sections of the instrument so as to determine the degree of internal consistency. The reliability coefficients of the items on psychological problems was 0.70 while a co-efficient of 0,77 was obtained for items relating to strategies for reducing the problems

\section{Data Analysis}

Data generated from the research was analyzed using the mean and the entire null hypotheses were tested with the t-test statistic at the 0.05 significant level. T-test was considered appropriate for testing the hypotheses.

\section{Results}

Analysis of the data yielded the following results as shown in the tables below

\section{Research Question one:}

To what extent do the designated psychological problems (self-esteem, emotional, fear) impact the female residents of the old people's homes? 
Table 1

Mean ratings of the perceived psychological problems of female residents in homes for the aged

\begin{tabular}{lllll}
\hline $\begin{array}{l}\text { Rank } \\
\text { Order }\end{array}$ & S/N & Clusters & & Decision \\
\hline 1 & $69-83$ & Emotional problems & 3.94 & Great extent \\
2 & $84-88$ & Fears & 3.80 & Great extent \\
3 & $59-68$ & Self-esteem & 2.80 & Great extent \\
\hline & & Grand mean & $\mathbf{3 . 5 1}$ & Great extent \\
\hline
\end{tabular}

In table 1, emotional problems (items 69-83) and fear (items 84-88) had mean rating above 3.00 showing that emotional problems and fear were psychological problems suffered by female residents of old people's homes to a great extent. Items 59-68 had a mean rating below 3.00. This indicates that self-esteem was not a problem. In essence, emotional problems and fear in that order were much of problems to the residents but self-esteem was not. Generally, the grand mean for the entire clusters was 3.51 suggesting that the female respondents rated that they experienced designated psychological problems to a great extent.

\section{Research Question Two:}

To what extent do the designated psychological problems (self-esteem, emotional, fear) impact the male residents of the old people's homes?

Table 2

Mean ratings of the perceived psychological problems of male residents in homes for the aged

\begin{tabular}{lcccc}
\hline $\begin{array}{l}\text { Rank } \\
\text { Order }\end{array}$ & S/N & Clusters & & Decision \\
\hline 1 & $84-88$ & Emotional Problems & 3.80 & Great extent \\
2 & $67-47$ & Fears & 3.91 & Great extent \\
3 & $48-58$ & Self-Esteem & 4.54 & Great extent \\
\hline & & Grand mean & $\mathbf{4 . 0 8}$ & Low extent \\
\hline
\end{tabular}

The result in table 2 shows a grand mean score of 4.08 . This means that male residents of old peoples' homes suffer the designated psychological problems. Self-esteem had a rating of 4.54 indicating that male respondents rated that they experienced self-esteem challenges to a great extent.

\section{Major Discoveries}

Consistent with the objectives of the study, research questions and data analysis the following findings were made that; 
- Male residents perceived more psychological problems than males did.

- Female residents rated emotional challenges and fears as more contributory to their psychological challenges.

- Male respondents rated self-esteem and fears as they greatest influencer of their psychological challenges.

- The residents perceived that policy enforcement, pension policies and medical services as key strategies to reducing psychological challenges.

- Residents of mission-managed homes rated their experiences of social problems more than the residents in government managed institutions.

- Both residents of mission and government managed homes experienced similar psychological problems.

\section{DISCUSSION}

The above discoveries are supported by a number of propositions according to Liddon, Kingeriee \& Barry (2018) over years scholars have established that men and women deal with psychological challenges differently. Women experience higher levels of depression and anxiety when compared with men while men, are affected more by self-esteem (Rosenfield \& Smith, 2010). A report by the American Psychiatric Association in 2000 established that women internalize depression, anxiety whereas men externalize their psychological challenges in activities such as substance abuse as well as anti-social behavior. As such, it can be deduced that residents of homes for the aged will show similar classifications and the male residents will be more destructive and problematic to others.

\section{RECOMMENDATIONS}

Based on the objectives and findings of the study, the following recommendations are made:

- Policy review of existing policies on the care of the aged in the society,

- Pension administration review

- More participation by the Nigerian government, re-training and employment of caregivers by non-governmental bodies, missionary and the government

- Integrating a gender based approach in counseling

- Ensuring adequate medical facilities are available

- Fast tracking medical response service to members of this elite group.

\section{References}

Abbah, T.\& Mabo, A. (2004), August,1). No one cares for the aged. Sunday Punch, pp3-4.

Adebowale, S. A., \& Atte, O. (2012). Elderly well-being in a rural community in North Central Nigeria, sub-Saharan Africa. Public Health Research, 2(4), 92-101.

Austen, S. (2016). Gender issues in an ageing society. Australian Economic Review, 49(4), 494-502.

Bamidele, S.N. (2005). The old in a depressed economy. BBC News/World/Africa. 429421.

Bahr, H. M., \& Bahr, K. S. (2001). Families and self-sacrifice: Alternative models and meanings for family theory. Social forces, 79(4), 1231-1258.

Beers, M. H. \& Berkow, R. (2004). The mark manual of medical information of health and ageing (3rd ed.) New Jersey: Merk Research Laboratories.

Dada, C.L. (2005). Is it ever enough to die of old age? Age and Ageing 32 (5), 484-486.

Ene-Obong, H. N., Onuoha, N. O., \& Eme, P. E. (2017). Gender roles, family relationships, and household food and nutrition security in Ohafia matrilineal society in Nigeria. Maternal \& child nutrition, 13, e12506.

Ferris, C.L. (2003). The Old People: Mastering the art of love and care through their experiences and stories. Baltimore:Publish America Books 
Foudaud, D. (2005). The role of elderly people in the era of HIV/AIDS in Africa. Families in Society, 75, 362, 282.

Hashimoto, A. (1991). Living arrangements of the aged in seven developing countries: A preliminary analysis. Journal of Cross Cultural Gerontology, 6(4), 12-23. Retrieved on 26 November 2006 from http://.ageing //onlineeduca.com/en.html

Ikoh, G.C. (2005). Capacity building and manpower training in elderly healthcare. Bold, 15(2),24-26

Irvine , R. E. (1986). Prospects in ageing. Bungau: The Chaucer Press Ltd.

Irvine R.E., Smith, B. J.,Bagnall M.K., Bishop, V.A. (1980). The older patient: An introduction to geriatric nursing (4th ed.). Bungau: The Chaucer Press Ltd.

Kolawole, T. O., \& Adeigbe, K. Y. (2016). Gender Discrimination and the Nigerian Scenario: A Review. Gender \& Behaviour, 14(1).

Liddon, L., Kingerlee, R., \& Barry, J. A. (2018). Gender differences in preferences for psychological treatment, coping strategies, and triggers to help-seeking. British Journal of Clinical Psychology, 57(1), 42-58.

Maslow, A. H. (1948). "Higher" and "lower" needs. The journal of psychology, 25(2), 433-436.

Mushtaq, R., Shoib, S., Shah, T., \& Mushtaq, S. (2014). Relationship between loneliness, psychiatric disorders and physical health? A review on the psychological aspects of loneliness. Journal of clinical and diagnostic research: JCDR, 8(9), WE01.

Ncube, N. (2017). Pathways to institutional care for elderly indigenous Africans: navigating contours of alternatives. African Journal of Social Work, 7(1), 44-51.

Nomaguchi, K. M. (2012). Parenthood and psychological well-being: Clarifying the role of child age and parentchild relationship quality. Social science research, 41(2), 489-498.

Obadina, E. (2005). Bosom of the family. New Internationalist, (264), 16-17.

Rosenfield, S., \& Smith, D. (2010). Gender and mental health: Do men and women have different amounts or types of problems. A handbook for the study of mental health: Social contexts, theories, and systems, 256-267.

Shofoyeke, A. D., and P. A. Amosun. "A survey of care and support for the elderly people in Nigria." Mediterranean Journal of Social Sciences 5.23 (2014): 2553.

Tanyi, P. L., André, P., \& Mbah, P. (2018). Care of the elderly in Nigeria: Implications for policy. Cogent Social Sciences, 4(1), 1555201 